\title{
What is Unifas and Why Should IFAS Faculty Enter Information into It? 1
}

Howard Ladewig and Glenn D. Israel ${ }^{2}$

\section{Introduction}

Unifas is a web-based information system for collecting information about a faculty members accomplishments in teaching, research, and Extension. ${ }^{3}$ The system is designed to help faculty provide stakeholders with a clear understanding of what faculty in the Institute of Food and Agricultural Sciences (IFAS) are achieving with the resources they receive.

One of the great strengths of IFAS is the integration of work between teaching, research and Extension. With Unifas, IFAS faculty have a comprehensive system to document these accomplishments.

\section{Measuring Organizational Performance}

During the 1990s, the Federal government and 47 of 50 states passed mandates for performance-based budgeting (Melkers \& Willoughby 1998). ${ }^{4}$ Organizations guided by performance-based legislation generally are expected to report annually on such performance measures as resources received, collaborations with other groups or agencies, products and services produced and changes made by those who use the products and services.

Federal legislation impacting IFAS include the Government Performance and Results Act of 1993, the Federal Agricultural Improvement and Reform Act of 1996, and the Agricultural Research, Extension and Education Reform Act of 1998. The latter two legislative acts required that a state-of-the-art information technology system be developed and used by the Secretary of Agriculture to evaluate agricultural research and Extension activities of land grant university partners with regard to outcomes of research and Extension programs, multi-state cooperation and integrated research and Extension work.

Several Florida counties also have similar requirements. In addition, decisions on national and state funding levels increasingly have shifted from line-item amounts to performance-based levels. In

1. This document is AEC-376, one of a series of the Agricultural Education and Communication Department, Florida Cooperative Extension Service, Institute of Food and Agricultural Sciences, University of Florida. Original publication date April 2006. Visit the EDIS Web Site at http://edis.ifas.ufl.edu.

2. Howard Ladewig, professor, and Glenn D. Israel, professor, Agricultural Education and Communication Department; Florida Cooperative Extension Service, Institute of Food and Agricultural Sciences, University of Florida, Gainesville FL. The authors wish to thank Emilio Bruna, Bobbi Henken, Betty Miller, Tom Obreza and Jeff Norcini for their constructive comments on an earlier version of this document.

The use of trade names in this publication is solely for the purpose of providing specific information. UF/IFAS does not guarantee or warranty the products named, and references to them in this publication does not signify our approval to the exclusion of other products of suitable composition. 
2004, for example, the Florida Legislature established a funding formula to measure workload and help establish budgetary levels for additional funding for research and Extension activities in IFAS. In fact, over $\$ 1$ million in new money was provided to IFAS for increases in research and Extension activities in 2005. Historically, IFAS research and Extension activities had been funded using a separate line item in the state budget.

A key part of performance-based budgeting is the use of a data-based management information system that links organizational budgets to faculty and organizational accomplishments. For IFAS faculty, that linkage is accomplished through Unifas. Data in Unifas is used to report workload measures ${ }^{5}$ to the Florida Legislature. Data also are used to document outcomes for research projects and Extension programs that are required by USDA in order to receive federal funds. This includes specific data on research appointments and Extension days expended, which are linked with salary data, to report the amount of federal funds used for multi-state and integrated programs. Unifas also is designed to be the initial source for answers to questions by legislators, commodity groups and university administrators. Finally, data on publications, grants, and project descriptions are used as a foundation for the annual research report while program descriptions and success stories are used for the content of the annual Extension calendar.

\section{Measuring Individual Performance}

Unifas also is used to link faculty accomplishments to tenure, permanent status, and promotion requirements of the University of Florida. In essence, faculty who correctly enter planning and accomplishment information into Unifas can generate tenure and promotion (T\&P) reports that conform to the Universitys and IFAS guidelines. Unifas reports also can be used by professors and Extension agent IVs eligible for the Salary Performance Program (SPP).

To meet university guidelines for tenure, promotion, and salary adjustments, the Unifas system developed the following modules:
- Personnel (rank, year of tenure, educational and employment history, specialties, intellectual property, honors, professional and scholarly service, etc.)

- Teaching (courses taught, course evaluations, guest lectures, graduate committee memberships, etc.)

- Research (selected data imported from CRIS, supplemented by text fields entered by the faculty member, as well as other projects entered by the faculty member)

- Extension (designed for tracking team and individual programs, with an emphasis on outcomes and impacts, as well as for recording clientele contacts)

- Publications (a complete database management tool for listing all publications by university T\&P guideline categories)

- Financial (grants and contracts from official sources and ones input by the faculty member)

\section{Unifas Design and Reports}

Unifas follows the axiom of "never entering what can be derived from other sources." To the extent possible, Unifas retrieves faculty information from official sources (CRIS, grants, courses, graduate students, course evaluations, EDIS publications, etc.). Unifas transfers information from appropriate data sources through an XML interface. In addition, for faculty who co-authored publications with IFAS colleagues, publication information need only be entered by one of the authors. The information will appear in the Unifas database for all IFAS authors.

Similarly, information is shared by Co-PIs for grants and research projects, as well as among team members for Extension programs. When faculty members are Co-PIs for a research project or team members for an Extension program, each one can add or edit common fields for the team. There also are fields for research projects and Extension programs that can be accessed only by the logged-in faculty member. 
Currently, IFAS faculty can generate three reports from the Unifas system: 1) an annual report of accomplishments; 2) a plan of work for the next year; and 3) a multi-year T\&P report. Each report can be edited with Microsoft's MS Word. After making desired changes, faculty should upload a copy to the Unifas reports repository. The edited $\mathrm{T} \& \mathrm{P}$ report also can be combined with supplemental materials (e.g., letters from the department chair and external reviewers) for submission as the final T\&P packet.

More detailed information on entering information into Unifas can be found at http://pdec.ifas.ufl.edu/unifas/tutorial/. In addition, resource assistance can be attained by contacting the Program Development and Evaluation Unit (PDEC) of IFAS at http://pdec.ifas.ufl.edu.

\section{Concluding Comments}

Unifas was brought on-line for faculty to use in January, 2005, and during the last year, major improvements have been made in the system. Given the dynamic nature of the information technology, Unifas will continue to be improved. Faculty are invited to share ideas with PDEC personnel for making the system easier to navigate and products that meet their needs.

\section{Reference}

Melkers, Julia \& Katherine Willoughby. 1998.

The state of the states: performance-based budgeting requirements in 47 out of 50. Public Administration Review, 58, 63-73.

\section{Additional Notes:}

3. The system was developed using Microsoft's Visual Studio, the .NET framework, and a SQL server 2000 database.

4. Arkansas, Massachusetts, and New York do not have performance-based budgeting legislation or mandates.

5. The IFAS funding formula includes five measures: 1) educational materials prepared (an original work such as a journal article, book chapter, fact sheet, or handout, but excluding newspaper articles and TV productions); 2) field consultations; 3 ) office consultations; 4) telephone consultations; and 5) group learning participants (clients present during workshops, meetings, seminars, field days, interactive video conferencing etc.) 